\title{
Tropics in the Snow: an Introduction
}

The supermarket presents us with a cornucopia of fruit, fish, and meat from near and far. Usually we haven't thought too much about how it all got there and the fact that we can enjoy fruit from the tropics all year round is something that we usually take for granted. But we are constantly reminded of the perishability of these refrigerated and frozen foods. Bananas, for example, are easily bruised and we know that they will spoil in a matter of days if we don't hurry up and eat them. Although other fruits, such as apples or oranges, might be a bit more resilient, it's still only a matter of time. And it takes just one rotten apple to spoil the barrel as the saying goes. We know that we have to rush fish, meat, and dairy products into our fridge or freezer, particularly on a hot day. The threat of putrification is constantly there.

Considering this everyday, practical knowledge we have about the perishability and fragility of refrigerated and frozen products, it is remarkable that they have survived the journey to our supermarkets from far away production areas. Not the least because a lot of fruit is grown in tropical backwaters or at least needs to cross the equator in their journey from the Southern Hemisphere to the North. "Six foot, seven foot, eight foot bunch!" is a memorable line from the Jamaican working song Banana Boat Song (Day-O) made famous by Harry Belafonte. Bananas have often been harvested, loaded and transported under the heat of the sun and stowed onto ships in small ports lacking infrastructure. The ships themselves have to sail across vast oceans through hell and high water. It's therefore not surprising that in the past bananas and other perishables often arrived in port rotten. Since the first steps in the second half of the 19th century, the cold chain, in other words the long chain of events from plantation, pasture, or fishing ground, to the retail outlet, has developed and become more reliable and resilient. But still, the core of the cold chain is still the same - highly sensitive and perishable products, still requiring high quality handling. The aim of this book is to throw light on a particular link in this cold chain, but let's start by taking a broader perspective.

Bananas and other fruit that we discuss in this book typically originate from farms or plantations in South or Central America, South Africa, or New 
Zealand. Sometimes they are carried in a refrigerated state, or sometimes in a non-refrigerated state by means of trucks, or possibly trains to a port terminal. There, they are reloaded onto ships, with the capacity to carry refrigerated and frozen cargo, which transport the produce to the consumption areas. This reloading is done by stevedores. Often, the produce needs to be stored for a shorter or longer time in the terminals. This can be done in conventional, nonrefrigerated storage, or in refrigerated storage, so-called cold stores. The maritime link, when bananas travel from Central America to Europe or the Us, or from the Philippines to Japan, or when fruit is carried from South America or South Africa to Europe, or when frozen meat is carried from for example New Zealand and Australia to Europe, Asia, and the Middle East, is the central focus in this book. When reaching the consumption markets, the cargo is discharged and then reloaded by stevedores onto trains and trucks which carry the cargo to wholesalers and then to the supermarket. The final destination is usually your fridge or freezer, tropics in the snow if you will. The details of the cold chain described above may vary somewhat but the model more or less applies to all cargo types. For fish and meat, the whole chain needs to be cold, while for some fruits, this need not be the case. Fish is sometimes brought from the fishing grounds to a port terminal where it is reloaded onto ships which take them to the consumption markets, but sometimes it is reloaded on the very fishing grounds themselves. The latter is called transshipment and is a delicate procedure where two ships need to be close to each other, often in difficult weather conditions.

The historical development of the cold chain that has led us to be able to experience the cornucopia will be touched upon incidentally in the book, but as stated, the main aim is to explore the maritime link - maritime reefer shipping - and more particularly one specific actor in the maritime link.

\section{Maritime Reefer Shipping}

The maritime link, which is often the longest link in the whole cold chain, relies on ships that are equipped to carry refrigerated cargo. It also relies on companies or people who own those ships, and companies that actually run the shipping operation, making sure that the right ship is at the right place at the right time. For the moment, we will focus on the companies running the operation of the ships, to introduce three different actors. We will first describe the actors briefly, and then turn to the ships. 


\section{The Actors}

Maritime reefer shipping can be catered for by the liner industry, which consists of shipping companies mainly dedicated to non-refrigerated cargo but which have the capacity to carry refrigerated cargo on their ships. They sail with scheduled departures. Examples of liner companies, which appear in this book, are Blue Star Line and Maersk. A second actor which can cater for maritime reefer shipping is the shippers, in other words, the exporters and importers. They might own or charter a fleet of specialized reefer ships that are primarily dedicated to carry their own refrigerated or frozen products. Examples of such actors are the fruit producers Chiquita and Dole. A third actor is the independent reefer operator. They are not in-house logistics departments owned by shippers but rather third-party, independent companies, who do not carry their own cargo. In this way, they are similar to the liner companies, but with a focus on refrigerated cargo and their operations are only sometimes based on scheduled lines. They are free to say yes or no to any business offered by shippers and are never primarily dedicated to carrying the cargo of one shipper only. A crucial aspect is that the independent reefer operator actively competes for reefer cargo amongst a number of customers. Examples of important independent reefer operators are Salén's reefer division and, after its bankruptcy, the reconstructed Cool Carriers, which were market leaders from the 1950s until the 1990s, Lauritzen, which was the first independent reefer operator, and Seatrade, which is the market leader today. The latter two types of actors are specialized, meaning that they are primarily dedicated to carrying refrigerated cargo, their own or that of others. What unites the two latter actors is that they operate reefers. But what is a reefer?

\subsection{The Reefer}

As has been described, refrigerated and frozen products can be carried either on vessels that are mainly carrying general cargo, but with refrigerated cargo capacity, or ships specialized for carrying refrigerated or frozen cargo. In this book, we call the latter category reefers. But many readers have probably heard the problematic word reefer in various contexts and used in different ways. This word has created significant conceptual confusion, so in the following section we'll try to both problematize and tidy things up.

To start with, the word reefer is just an abbreviated way of saying refrigerator and it has been used over the years to refer to all sorts of refrigerated units from train cars to household refrigerators. However, in a maritime shipping context, it traditionally refers to a cargo ship with the capacity of carrying refrigerated cargo. 
Many of the early ships were multi-purpose, being able to carry general cargo, passengers, and some of their holds were insulated and could be refrigerated. These vessels are occasionally referred to as reefers, or part-reefers. However, in this book, we do not define these general cargo ships with some refrigerated capacity as reefers.

A term that sometimes crops up is the "freezer" which is a vessel capable of freezing, but not cooling, its entire cargo. These, usually smaller vessels, have been widely used to support the fishing industry, carrying the produce from sea to shore. These "freezers" are sometimes called reefers, and sometimes not. The earliest specialized reefers, back in the nineteenth century, were all freezers, yet they are usually referred to as reefers. The main point was that reefers could both cool and freeze their cargo, while freezers could only freeze their cargo. Some freezers were later rebuilt with more temperature control, which effectively enabled them to carry non-frozen cargo such as fruit, which turned them into reefers. In this book, we include freezers as a subset of reefers, but we still use the word freezers as a way to indicate this particular type of ship.

There were several material features that emerged during the twentieth century, besides refrigeration, which can be said to be typical of reefers. One of them was speed. Reefers were usually faster than regular cargo ships and the need to rush perishables to the market is understandable. Another feature relates to port access. Many small ports are not accessible to larger vessels, but it so happens that the refrigerated trades are particularly reliant on these. They can be tropical ports, small and undeveloped, but a tremendous source for bananas and other fruit. Reefers have also called on small fishing ports in the far north and on the southern tip of South America, as well as the Falklands. This effectively limits the size of reefers but also makes a shallow draft advantageous. A third feature is the priority placed upon the ship's own ability to handle cargo. Loading and unloading cargo breaks the cold chain, so reducing the time that perishable cargo spends between the port's cold storage facility and the reefer ship is important. Reefers are therefore well-equipped with their own derricks, and later on cranes, since infrastructure has usually been lacking in the small ports they call upon. It's also the case that major ports may experience delays that may be circumvented because of the reefer's own capacity in this regard. So to sum up, speed, smallish with a shallow draft, and wellequipped with derricks or cranes are features that are usually associated with reefers.

Until the early 1970s the reefer cargo was stowed and stacked in "breakbulk". This could be in nets, sacks, boxes, barrels etc. Banana stems were just stacked in the early days. However, since the 1970 s maritime reefer shipping increasingly moved towards the carriage of palletised cargo. These reefers were 
frequently termed pallet-friendly reefers or simply modern reefers in contrast to the old breakbulk reefers. Refrigerated containers began to make serious inroads into the refrigerated shipping market in the 1990s, and these containers are also referred to as reefers, but in this book we identify them as reefer containers. During these years it is common to read the phrase conventional reefer to mean a ship with refrigerated holds as distinct from a container ship carrying refrigerated containers. Occasionally, the reefer was also referred to as a bulk reefer. For many years a distinction was maintained between conventional reefers and the container ships (partly equipped to carry reefer containers) operated by the container lines. Reefers it was held, were not, by tradition more so than by any logical definition, container ships. This distinction became increasingly difficult to maintain, since the so-called conventional reefers were, with each successive newbuilding, equipped to carry increasing numbers of refrigerated containers. These vessels may be termed hybrid ships (refrigerated holds plus refrigerated containers) but at the time they were just considered reefers with high container capacity, sometimes they were, once again, labelled modern reefers.

Specialized container ships designed to primarily, or only, carry refrigerated containers began to appear in the years around 2000 and they were frequently termed reefer-container ships, but with time increasingly just reefers or reefer ships. Since we term any ship which is primarily dedicated to carrying refrigerated cargo a reefer, we also call these ships reefers. The latter term clarifies that it is the ship and not the reefer containers carried onboard that counts. In recent years the operators who controlled conventional reefers, have begun to use the term specialized reefers. So what at the present distinguishes the specialized reefer is not whether the cargo is stowed in containers or in a hold, but rather that the ship is primarily designed to carry refrigerated cargo directly and without delay to its destination. Interestingly, since the appearance of containerization, palletised reefers are sometimes called breakbulk reefers ${ }^{1}$.

So what is a reefer? As we've seen, exactly what is meant by the word, and how it has been used, has changed over time. After this conceptual exercise, we conclude that the best definition of a reefer ship is perhaps the simplest one: A ship specialised for transporting refrigerated cargo. We are back to where we started, but hopefully with a more nuanced understanding of this very central concept.

1 "Carriers put money on hybrid ship designs", Shanghai Shipping Exchange, 19 November 2012, $<$ http://en.sse.net.cn/info/detailen.jsp?id=310233>. 
After this brief introduction to the artefacts and actors involved in both the cold chain and maritime reefer shipping, it is possible to position this study. In this book, we focus on studying the independent reefer operators. Similar to independent tanker companies (not owned by either exporting oil companies nor importing companies), bulker companies, and liner companies, these independent reefer operators are unambiguously a part of the third-party commercial shipping industry for which shipping is not only a support function but the main business area. For this reason they should be as important to study as other third-party shipping companies, although the current scarcity of studies might be due to the discourse of decline and the fact that they employ less capital than for example tankers and bulkers. Since it is their core business, the study of the independent reefer operators is a direct way of studying maritime reefer shipping and, in a more indirect way, the cold chain.

Given its position as an intermediary between shippers and ship-owners, the independent reefer operators have a challenging position, having to please both these stakeholders as well as being profitable themselves. As Wijnolst and Waals ${ }^{2}$ indicate, there is a great discrepancy between ownership and operation in the reefer industry. Most of the independent operators' tonnage is owned by others, which means that the operators have a great market presence despite having a low degree of ownership - this precarious position is interesting to study from the perspective of business strategy. How do the independent reefer operators manage to stay in business and be profitable over time?

One should also note that there is a methodological reason behind studying the independent reefer operators - a question of access. Given previous studies, one of the authors had already discussed the reefer industry with representatives of Salén, Cool Carriers and Holy House. This preliminary study made it possible to get access to more respondents through the contacts that were made. Given that the study started with one independent reefer operator it was possible to get access to all reefer operators, but it was more difficult to get access to ship-owners, and even more difficult to get access to shippers. Also, the independent reefer operators are limited in numbers which also makes it possible to study them in a comprehensive way. The same cannot be said about shippers and ship-owners. For these reasons, we hold that the independent reefer operators are a suitable looking glass not only for reaching a deep understanding of this type of actor, but also to shed some light on the

2 Wijnolst, N. and Waals, F. 1999. Shipping Industry Structure, Delft: Delft University Press. Chapter 7, pp. 138-160. 
broader functioning of the cool trades, which could be explored in future research.

One can approach these operators both collectively and individually. Approaching them collectively means that one sees them as a set of companies which share some main characteristics, and are different than other sets of companies, such as liner companies. This approach would study how and why they emerged as an alternative to the liner companies, what led to their dominance in the carriage of refrigerated and frozen cargo, and their subsequent decline. Approaching them individually means that we can also recognize their particularity which is due to their different origins, resource bases, and strategies. Given the empirical material that we present in this book, the differences between the different companies are obvious and to neglect these differences would not give an accurate perspective of the development the independent reefer operators. An immersion in the empirical material has led us to focus on the strategies the various actors adopted, and how they tried to compete with each other and with the liner companies. We take a particular theoretical perspective when studying the independent reefer operators, which we will explain later in this introduction. But already here we can say that rather than conceiving the maritime link as just a logistical operation moving goods from A to B, we will study not only this material reality, but also the way the independent reefer operators make sense of themselves and the industry, and the psychological drivers for their business decisions.

Our research question in its simplest form is: How have the independent reefer operators developed, individually and collectively, since their beginning until today?

This book aims to contribute to business studies and maritime history by providing a historical analysis of the independent reefer operators. Such comprehensive studies have not been done before and given that the maritime transport of refrigerated products has been a well-defined niche in the shipping industry, it is important to describe it and shed light on its historical development. Furthermore, the book contributes by understanding and problematizing the workings of the industry by means of our three-dimensional theoretical framework - its material base with ships and cargoes, how actors within and outside the industry make sense of it by means of discourses/talk/language, and the psychology of the actors involved. This theoretical approach fits into current calls for more theoretical studies within the field of business history ${ }^{3}$. We believe that a deeper understanding of the independent

3 See for example de Jong, A., Higgins, D.M. and van Driel, H. 2015. Towards a new business history? Business History, 57: 5-29. 
reefer operators can also lead to insights into the driving forces of the shipping industry.

\section{4 Independent Reefer Operators and Their Customers and Suppliers}

Having specified the aims of our study, we will now give an overview of the actors involved in the maritime link and the various strategic choices they are confronted with. Many of the dynamics emerge through interactions between the independent operators and other actors, and it is therefore of importance to understand the context in which the independent reefer operators find themselves.

\subsection{The Shippers}

The independent reefer operators are embedded in a transport system, where shippers - in other words, those who want to transport cargo to the buyer, or those who want to transport cargo from the supplier - decide how to ship their goods, whether on their own ships, by means of short term contracts with shipping companies, or in some cases even outsourcing the whole shipping activity to shipping companies. While these actors are very important in the reefer industry, they are not covered as thoroughly, since our main purpose is to study the independent reefer operators - in other words, those actors who cater for the transport services of the shippers. These actors are often more or less independent from the shippers, in the sense that they are not owned by the shippers nor fully restrained by the desires and agendas of shippers. It should here be noted that if all shippers decided to organize their transport based on their own ships, there would no need for independent reefer operators. However, in the industry's history we have seen that in some phases shippers have wanted to own their fleets, in some phases they charter ships, and in some cases, they decide to collaborate with an independent reefer operator or a liner company to ensure a cost-effective and secure transport system. And of course, combinations of these different choices.

It is generally the demands of the shippers and the buyers which decide how much maritime shipping capacity is needed in the industry. The major categories of refrigerated goods to be transported across the ocean have been quite stable during the era of the independent reefer operators which tentatively started in the 1930s. As will be explained in chapter 2, the reefer industry as a whole started with meat and was followed by bananas, other fruit, and fish. These different cargo categories have their own inherent dynamics. Bananas have been the absolutely most important reefer transport commodity during 
the era of the independent reefer operators, occupying approximately $40 \%$ of transported volumes ${ }^{4}$. Apart from volumes, for the shipper to understand how much tonnage is needed, there is also a need to know the distances the produce is transported. For example, a round-trip that last twice as many days with the same amount of cargo will require twice as much tonnage. We can illustrate this perhaps easiest by considering the following example. A large trade takes place with bananas from the Philippines to Japan since the 196os. Failed harvests in Philippines, due to bad weather for example, means that Japan might source its bananas that year from Ecuador. The result is that the shipper needs more shipping capacity during that year.

Bananas are produced throughout the year but most other fruits, for example apples, grapes, citrus and kiwifruit, are seasonal. When such fruit ripens in the Southern Hemisphere, it needs to be transported to the major consumption markets in the Northern Hemisphere. These seasonal volumes are usually fixed by short-term time-charters and any excess is picked up by the spot trade. For the shippers, the spot trade acts as a kind of reserve shipping capacity. Shippers are reluctant to contract their entire anticipated requirements since inclement weather, for example, can destroy the harvest. A bumper crop on the other hand, means that there will be a shortage of shipping which will in turn lead to high spot rates. Graph 1 shows the average spot rates in the mid 1990 f for the purpose of showing the significant variation of rates throughout the year with high demand, and thus high rates, in March and April. This seasonal variation is what allowed some operators of old tonnage to sail in the peak months and then have their vessels in lay-up during the off-season. It can be estimated that the transport demand in the high season can be between $5^{0-}$ $80 \%$ higher than in the low season ${ }^{5}$.

So, the demand for ships is determined by the volumes as well as the distance between production sites and consumption markets. The demand for imported refrigerated goods is related to consumer purchasing ability which is in turn influenced by both the availability of supply (i.e. pricing) and the effects of economic recessions and periods of prosperity. Demand can also be stimulated or otherwise by social factors: health consciousness, fashion and marketing initiatives.

Major reefer fruit trades include the banana trades from South and Central America to the USA (see Graph 2) and to Europe in particular. Bananas from the Philippines are important as are New Zealand's apple and kiwi exports. Grapes from Chile and South Africa, citrus from for example Morocco, Israel

4 "Kylsjöfart". Svensk Sjöfarts Tidning 1993/50, pp. 72-74.

5 "Kylsjöfart". Svensk Sjöfarts Tidning 1993/50, pp. 72-74. 


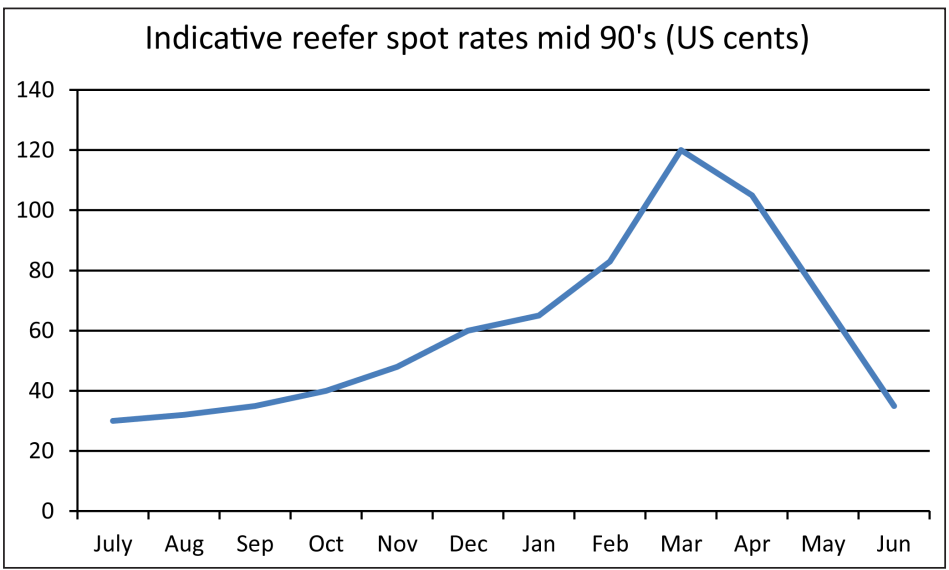

GRAPH 1 Indicative reefer spot rates mid 1990 (Us cents)

Note: Lauritzen Cool in Perspective, 2003.

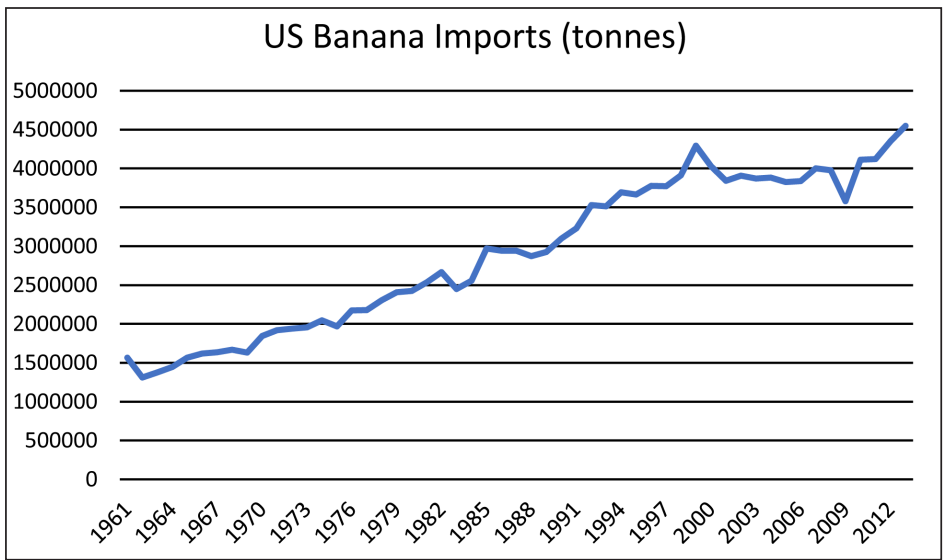

GRAPH 2 US banana imports 1961-2013. Transporting bananas to the USA is a major business for maritime reefer operators, only the banana trade to the European Union is larger.

Note: (c) FAO, Food and Agriculture Organization of the United Nations <http://www.fao.org/faostat/en/\#data/TM>

and other places and our list of important trades could include pineapples, melons and tomatoes and so on. And in most cases the destination has historically been the us, Europe or Japan. These major consumption centres are also important destinations for fish and squid which can come from places such as the South Atlantic. The meat trades from Argentina and Australia to originally 


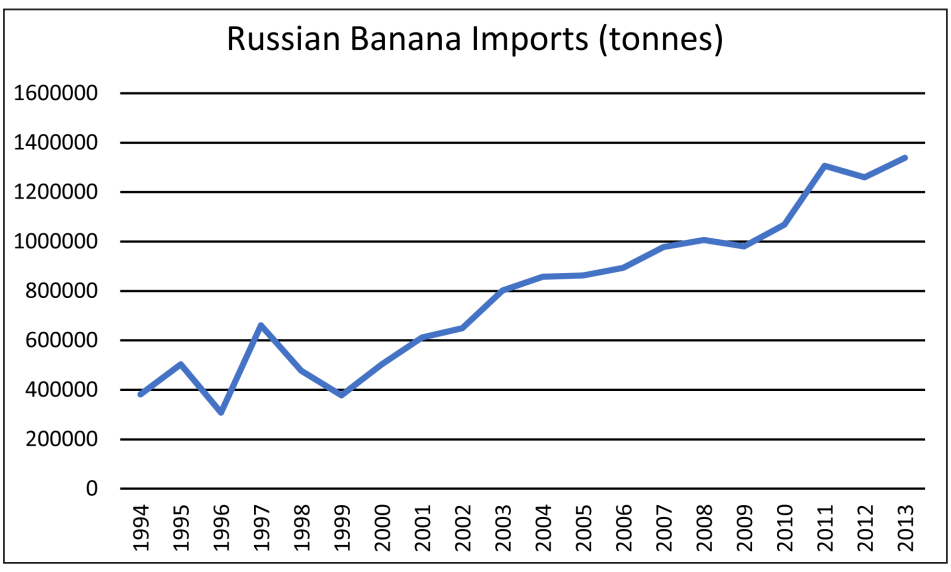

GRAPH 3 Russian banana imports (tonnes) 1994-2013. Russia's banana imports have increased significantly since the late 1990 . Note: (c) FAO, Food and Agriculture Organization of the United Nations <http://www.fao.org/faostat/en/\#data/TP>.

Europe and later the USA are large and these trades were early to be containerized. The demands of the consumption markets have changed during the studied period. For example, after the collapse of the Soviet Union more fruit, fish and meat were imported into Russia and other Eastern European countries. Russia has become a large banana importer in recent years (see Graph 3), particularly from Ecuador.

Also, the development of China the last two decades has had an impact on the market. Furthermore, one can see the growing importance of supermarket chains, with the likes of Walmart and Tesco having significant buying power. Moreover, there have been significant regulatory changes, first in terms of the deregulation of import and export markets, hand in hand with the penetration of economic liberalism throughout the world. Import and export boards have been replaced by a more free-market structure. This has altered the environment in which independent reefer operators act.

The strategic choices of shippers depend on what kind of shipper they are. Some shippers in the meat trade have during some periods had an entire integrated value chain, owning everything from cattle, abattoirs, cold stores, ships, and retail outlets. Banana majors have the possibility to either own their ships, charter ships from an independent ship-owner or let an independent operator do the job. Often they choose a combination. As we will describe in the following, the shipper might consider that transport is or is not a core business worth to invest money in. A main question for the shipper is whether the money 
employed when buying and owning ships is adequately invested. Maybe one should rather aim at improving plantations and acquiring more fertile land? But how can one ensure that the independent reefer operators will do their job? Sometimes strategic partnerships are formed between shipper and operator. When it comes to shippers of other fruit, due to their seasonality, it is less likely that the shippers will buy their own tonnage. Rather, as has been described, they employ ships on time-charters and on the spot market. A strategic decision here becomes how much tonnage should be time-chartered, what tonnage, and from whom. The shipper of course wants to see the cargo arrive in good condition without delays. Failure to do so will lead to various kinds of discussions and settlement between the shipper and the ship-owner and/or operator.

The shippers pay the operators or ship-owners on the basis of the transport capacity of the ship and also the potential of other alternatives. The transport capacity includes the carrying capacity of the ship, the speed (since a faster ship can transport more volumes in a give time period), the bunker consumption (a highly fuel consuming ship leads to more costs), the cargo handling equipment (since it affects the time in port), and other extras. The sine qua non is of course that the ship should be able to carry the produce of the shipper. Freezers might not be able to carry bananas, and so on. An extra bonus can be paid for going to far-off or more inaccessible areas.

The shippers also pay the operators and ship-owners on the basis of available alternatives, such as carrying the cargo on competitors' ships, and on liner vessels or container lines. Sometimes a lower rate can be perfectly fine for a ship-owner that owns old, depreciated ships. And sometimes the shipper, given the alternatives of a cost-competitive liner service, cannot or will not pay a significantly higher rate for transporting cargo in a reefer. A premium over the low-cost alternative by a certain percentage might be acceptable.

Since shippers do not own all the means to take care of their maritime shipping needs, there is a reefer shipping industry, which consists of a few major kinds of players.

\subsection{The Ship-Owners}

Ship-owners invest in a ship using equity, loans and/or other forms of financing. The investment can either be done on speculation (without a clear customer in mind) or based on a customer's particular requirement. To secure a long time-charter is often a requirement from the ship-owner in order to build a new ship. Therefore, the banana companies with their stable and non-seasonal trade are excellent business partners for a ship-owner who wants to construct new vessels. 
After the ship is owned it is either chartered to a shipper or time-chartered to or allowed to be used in a profit sharing scheme by an independent reefer operator. A ship-owner can have various motives for owning ships. Ships can be used as a way to generate profits through their everyday operation, and then it is important that the income exceeds operational and capital expenditure. They can also be primarily aimed at the increase of ship value, for example that the ship is bought before the market goes up and sold when the market has risen. A ship can also be used as an investment which allows the main owner or related co-owners to reduce their tax burden. A merchant ship is a major investment and yearly depreciations can dramatically cut the tax burden of other businesses.

Sometimes the ship-owners are highly knowledgeable about shipping, but sometimes they see the ships as pure financial investments and rely to a greater extent on the judgment of the independent reefer operator or shipper. What are then the strategic options available to a ship-owner? It is to decide if one should own ships, if more ships should be bought, or if ships should be sold. Strategic choices can also concern how the ships should be maintained - how much money should be spent on maintenance and what crews are suitable? Here there are questions of short-term or long-term cost, quality, and longevity of the ship that are central. Given the different motivations of the ship-owners, it could be the case that a ship-owner buying ships for speculative ends might be less interested in excellent maintenance for the longevity of the ship, but it is not certain. The maintenance could be done in-house or by independent ship management companies, thus allowing the ship-owner to strike the balance between in-house full control and dedication (but also being tied up with costs) and outsourced operations, where there is often access to more competence, but where the ship-owner is one amongst many.

The ship-owner must also choose where to flag the ship. Depending on which flag state a ship-owner chooses, the ship can be employed in different trades and are subject to different regulations when it comes to manning, technical controls, etc. Most ship-owners have during the century which is the focus of this book moved away from national flags to flags of convenience, meaning flag states where the demands on crewing and technical maintenance is lower, and states where the tax regime is beneficial ${ }^{6}$. Flag states regulate various aspects connected to running ships and sometimes there are also

6 Carlisle, R. 1981. Sovereignty for Sale: The Origins and Evolution of the Panamanian and Liberian Flags of Convenience, Maryland: Annapolis. De Sombre, E.R. 2006. Flagging Standards: Globalization and Environmental, Safety, and Labor Regulations at Sea, Massachusetts \& London: Cambridge. 
international consequences. For example, reefers flagged to certain states could not be employed in the squid trade during the Falkland Islands conflict. Many ship-owners in the 1930s transferred their vessels to the flags of countries that it was assumed would be untouched by the upcoming war. Avoiding wartime confiscation was one of the reasons for the emergence of flags of convenience, another reason was to bypass the prohibition of alcohol in the USA after 1922. Moving on from flagging, it is worth noting in this context that political actions, such as trade embargoes, impact on shipping. For example, Russia has reduced its imports of frozen poultry from the USA during times of poor political relations. This has immediately affected the market and for carriers of frozen cargo it's been anything but good news. Trade embargoes of particular products or against particular countries impact on shipping. Vessels that have called on Israeli ports have sometimes not been welcome in certain places.

When it comes to commercial operation, the ship-owner can commercially employ the ship in-house. But as we have mentioned, there are other options. A time-charter agreement with a shipper or an independent reefer operator is a common choice. The shipper or operator thus agrees to pay the ship-owner a rent to be allowed to use the ship in their operations. There can be timecharter agreements ranging from weeks to years. The profitability of the ship-owners' business becomes quite predictable, since the ship-owner more or less knows the income and the cost of owning the ship. Several risks remain, for example, technical breakdown or the risk that time-charter agreements will not be prolonged, or that they will be cancelled. If time-charter business is the main business of the ship-owner, there is often no need for a large commercial function. However, the time-charter rate is a negotiated price which is often a win-win situation for several parties, meaning that the ship-owner could potentially reap even more profits if she decides to operate the ship herself. For example, a time-charter rate might be based on the shipper's assumption that the ship will sail with no cargo back across the Atlantic. But if the ship-owner knows that there is indeed a profitable return cargo that will not delay the ship significantly, the ship-owner might see even more potential for profit. Then, she could decide to operate the ship herself. One option is to operate the ship on the spot market. When a cargo is available, the ship-owner has a potential to transport it by offering the best price and conditions. However, some shipping markets have a more developed spot market than others (for example crude oil transport). It is widely considered that the reefer market is not and has never been one of them. This could lead to significant risk for the ship-owner that the ship will be unemployed, generating cost but not income.

Another possibility is to have contracts of affreightment, which means that the ship-owner binds herself to doing a number of voyages for a shipper during 
a specified time period. During the time when the ships are not employed by the shipper, the ship-owner has the opportunity to use the ships in whatever way she deems fit. This is, in a sense, a middle ground between the time-charter and the spot market. The ship-owner can also offer the ship to an independent reefer operator. The operator often has a large number of ships and the ship-owner gets a share in the profits from all the ships. This share corresponds to the size, speed, age, etc. of the ship. For the ship-owner, the independent reefer operator works according to best effort, and can therefore render larger profits than a time-charter agreement. Also, since the market risk is shared with other ships, there is often a minimal earning that is higher than the worst calamity on the spot market. So, for the ship-owner, the decision whether to employ the ship on time-charters, contracts of affreightment, the spot market, or with an independent reefer operator is dependent on several factors. Timecharter requires less work and leads to a stable income during a time period. Contracts of affreightment leads to stable income for some consecutive journeys and the possibility of extra profits from the time in-between. However, it requires more work and pesonnel in order to find the cargo to transport. The spot market requires even more management and expertise but has the potential to reap even higher profits, if the spot market in the particular shipping industry is healthy.

\subsection{The Independent Reefer Operators}

The central actor for this study is the independent reefer operator. The operator is an intermediary, or middle-man, between shippers and ship-owners, using the ship-owners to secure ships and marketing these ships to the shippers, alternatively securing a contract with a shipper and securing ships with a shipowner. In a sense, the operator takes on market risk and gets the chance to reap profits. We have seen that ship-owners can also market ships to customers, but a main importance is that an operator markets the tonnage of various shipowners. The operator itself can also be a ship-owner, but only if it markets other tonnage as well, do we classify it as an operator. Wijnolst and Waals give a comprehensive description of the reefer industry until $1995^{7}$. Apart from surveying the state of the art of the reefer market, they pay explicit attention to the ownership structure of the industry, noting that the biggest owner in 1995, Seatrade was owning a mere $3.5 \%$ of the world reefer fleet. The authors also pointed out how reefer ships are arranged in different pools that have a larger market share than is visible in the ownership numbers. According to Wijnolst

7 Wijnolst and Waals 1999, pp. 138-16o. 
and Waals the more detailed analysis of such operators is left undone, which is a reason why we attempt such an analysis in this book.

There are mainly two ways for the operator to secure a ship. The operator can either timecharter ships from a ship-owner, or they can convince the shipowner to let the operator employ the vessel to take a share of the income of the operator (without any promises of a rate). It is of course assumed that the income is greater than if the ship-owner would have employed the vessel by herself or charter it to a shipper. If the ship is timechartered the operator pays a monthly rate to the ship-owner, which makes it possible to earn but also lose money if the differential between the market level and the timecharter rate is significant. Also, the independent operator can own ships. The line between a ship-owner and an operator is not fixed. We will see periods in time, where ship-owners become operators and vice-versa. Sometimes we will describe how much external tonnage an operator controls to get a glimpse into to what extent they are a traditional ship-owner and to what extent they are an independent operator.

The operators have the shippers as customers and sign short-term or longterm contracts of affreightment or time-charter contracts with the shippers. Some specific ships might be fixed, or employed, with a shipper. Other ships can be arranged in a so-called pool. In this pool, all constituent ships share the revenues from the pool. The ships share the revenues not equally but depending on the ships' capacity, speed, consumption, age, cargo handling equipment, and other potentially relevant factors. When many ship-owners collaborate, issues of fairness will constantly crop up, and it is important that ship-owners perceive there to be fairness. An operator can have different pools, similar to a market segmentation. For example, small ships suitable for fish trades can be in one pool, while larger ships suitable for fruit transport might be in another pool.

Independent reefer operators usually control more ships than ship-owners do and this is why they are able to secure higher proftablity. They can optimize transport patterns. For example, in the periods in which a ship is not needed by a shipper, the operator can employ the ship in other trades needed by other customers. The operator also has constant contact with several market channels and in general has more insight into the market than do single ship-owners. Also, since at least theoretically, any ship in the pool can take a particular cargo, the independent operator will always have ships closer to the customer due to their market scope.

An illustration of how to increase the utilization of vessels follows. An operator has been given the contract to take squid from the Falkland Islands to Japan. Finding suitable backhaul cargo on the return leg to the Falklands may 


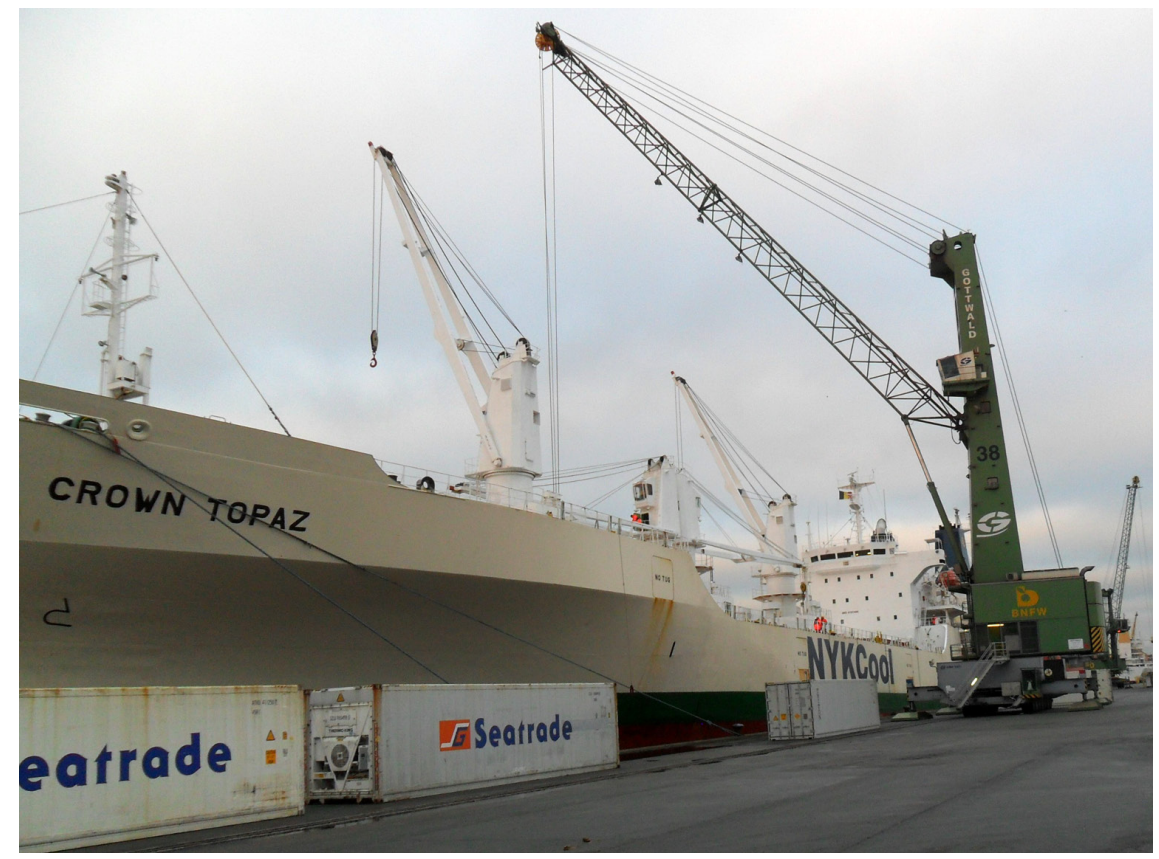

FIGURE 1 Finding backhaul cargo and repositioning empty reefer containers are two problems facing operators. Pictured is an NYKCool reefer loading its competitor's empty containers as backhaul cargo to the Caribbean. Antwerp, 2014 PHOTO: P. BIRCH (AUTHOR)

be impossible, although some reefers with large fuel tanks have transported bunkers there. But, perhaps second-hand Japanese cars can be carried to Buenos Aires or maybe to Valparaiso. The reefer operator could offer a low rate for this transport, as the alternative would be to sail empty.

The role of the independent operator is often quite precarious. There is the constant risk of ship-owners thinking that they can do better themselves, or with another operator. Much of the success of the independent reefer operators is built on that the ship-owners believe that they are maximising their revenue. The independent reefer operators therefore need to keep the shipowners loyal, both by actual revenue, and by expectations of large revenues in the future.

An operator is often a big actor that has direct relations to major customers. Sometimes operators want to integrate across the value chain and offer doorto-door services. In other words, that the produce is picked up with trucks, transported by ship and then with train and truck again until reaching the final destination with all transports arranged by the reefer operator. With such 
strategic decisions, the operator can solve the customer's problems, but it also requires the necessary personnel and administrative skills to handle the relations to various actors in the supply chain. When venturing into land transport, new competences are needed, which the company might or might not have.

We have also mentioned the development of transport of reefer cargo with large container lines. These companies, such as Maersk and MSC, can also be conceived of as operators who offer transport services to shippers. The distinction between the container lines and specialized reefer operators is that reefer operators are usually shipping the cargo faster and more directly in purposebuilt ships, while container lines carry different kinds of containerized cargo in a logistical network. A frequent discourse in the reefer business is that independent reefer operators offer a taxi service, while container lines provide a bus service. We can therefore see that operators need to make strategic decisions when it comes to what service they are offering, in terms of price, time to market, quality, etc.

\subsection{Brokers}

Another kind of company is the broker, which connects different actors in the industry. Brokers can help operators to find shippers and help shippers to find ship-owners or even operators (although they are quite well-known). There are also sales and purchase brokers, helping ship-owners to find good appropriate ships to buy, and newbuilding brokers, who are middle-men between shipyards and ship-owners.

We have now described some main actors in the specialized reefer industry, but it must be emphasised that the same company can belong to different categories. It is possible that an operator is also a ship-owner, or vice versa, and that a shipper primarily operates its ships on the international competitive market (outside the transport needs of the shipper itself). Furthermore, another consequence of this situation is that the independent reefer operators are indeed dependent, in the sense that they are always part of an industrial network. When we study their strategies, we are well aware that their freedom to act and formulate strategies is very dependent on the network they are part of. Even though we study the independent reefer operators, it is likely that sometimes their strategies have been highly influenced by other actors, for example their customers. Actors have historically played different roles and had shifting power relations. Therefore, in our study, incidentally, we problematize the 
locus of strategy - the power to act and influence a company's own development as well as the direction of the industry.

Corporate actors are often seen as the main locus of strategy, but it is important to note that they cannot make decisions. People make decisions, for example as individuals, or as groups and networks of various kinds. In the study, we will shift our view between various actors and their strategic choices, in order to problematize the locus of agency that is sometimes assumed to be the top management in organizations. In our study, we will show that it is sometimes the customers, sometimes a community of employees, sometimes the owners, and indeed sometimes the top management who shape strategy. We will therefore argue that there is an intricate web of actors and decisions that together has shaped the development of the independent reefer operators.

Although we are interested in being close to the empirical material in this book, we are aware that much has been written about strategy, also in the shipping industry, and it is helpful to survey the various strategic options that actors can choose. Researchers Niemié and Germain ${ }^{8}$ describe earlier research on shipping strategy stating that shipping companies can engage in differentiation - meaning that they do things differently from the competition, thereby creating a value proposition that is attractive to the customers. Rather than just moving goods from A to B, shipping companies can add terminal operation, warehousing, increased geographic coverage, added frequence or directness of sailings, and so on. By doing this the shipping company can charge a price over the market price. Some smaller players might adopt the strategy of concentration, or in the Michael Porter's words focus, where they focus on a specific geographic segment, or other kind of niche of a shipping market. Defining what constitutes a niche is of course debatable. Something is always a niche in relation to something else, and there can be niches within niches. For example, reefer shipping can be considered a niche within the broader shipping industry. Focusing on time-chartering vessels to major banana companies would then be a niche within the niche. Shipping companies can also adopt a strategy of cost leadership - being the cheapest company to offer the service. This could be achieved by having an older fleet, for example, with ships that are already amortized.

Niemié and Germain connect the shipping literature to Igor Ansoff's strategy of diversification, which means that a shipping company manages risk by not putting all eggs in one basket. The company can invest in other maritime sectors than the one they are operating in, or in non-maritime sectors, such as

8 Niemié, O. and Germain, O. 2014. Strategies in Shipping Industry. A Review of "Strategic Management" Papers in Academic Journals, Working paper, ESG/UQAM. 
real estate or finance. However, strategic choices do not always fit neatly into these frameworks. Companies can choose to collaborate with customers, suppliers, or even competitors, in order to increase the competitiveness of the company. Similar literature sees networks and business relationships as a crucial aspect for strategy 9 .

Niemié and Germain's study concludes that much of the strategic literature on shipping is outdated theoretically. It remains quite rationalistic, in that companies are assumed to formulate their policies after having done a rational assessment of the situation. It also excludes novel theoretical discussions in the broader field of strategy, for example sense-making perspectives, which highlights how strategies are formulated with reference to many more aspects than the so-called (material) reality, for example stories, myths, collective (mis-)perceptions. In this study we use a theoretical framework that hopefully goes beyond the often-used theories of Porter and Ansoff, and thereby throws additional light on what shipping companies are doing and why. It is to this framework we now turn.

\section{Three Theoretical Dimensions of Business Activity}

We present three dimensions that are important for the study of businesses or industries: the material, the discursive, and the subjective. This is a framework that was developed by the philosopher Alain Badiou and utilized in business studies to study the shipping companies Stena Bulk and Concordia Maritime ${ }^{10}$. In that study, it was argued that the promotion of a particular concept of "quality" was carried out both through discourses (such as "oil should always travel first class") and symbolism, such as the visual representation of ships. This had an impact on how quality was framed within the oil shipping industry. Although this can be dismissed as just irrelevant "talk" and "images", it had a real impact on material dimensions, such as scrapping rates.

9 Håkansson, H. and Snehota, I. 1989. No business is an island: The network concept of business strategy. Scandinavian Journal of Management, 5: 187-200. Håkansson, H. \& Snehota, I (eds.). 1995. Developing relationships in business networks. London: Routledge.

10 Lennerfors, T.T. 2013. Att skapa en värld - Stena Bulk, Concordia Maritime och marknadsföringens betydelse i tanksjöfarten 1982-2012, Gothenburg: Breakwater Publishing in collaboration with BAs. Other studies that use a discursive approach are Forsberg, P. 2001. Berättelser och omdömen i en redares vardag, Göteborg: BAS. Guy, E. 2013. Representations and policy change: evidence from the Canadian-flag shipping industry. Environment and Planning A, 45: 1184-1198. 
Our reason for dividing reality into these three particular dimensions is because we hold that they provide a novel and productive reading of the independent reefer operators. The main distinction from established analytical frameworks is that the utilized framework highlights the role of discourses, language, sensemaking, as well as the psychological drivers behind the development of this industry.

The subjective dimension was later updated based on more recent work by Badiou to encompass Plato's concepts of eros, thymos, logos, which will be explained below ${ }^{11}$. The present book connects these two triads and develops them further and is therefore part of the explorative project of utilizing philosophy to understand an industry.

Many industrial studies have focused on either the material dimensions, for example the size of markets, or availability of capital. Other studies have spotlighted the individual traits of a particular entrepreneur. Business studies have also followed the discursive turn in social sciences to understand underlying structures of sense-making in organizations. However, this study encompasses all of these perspectives. The advantages of combining these dimensions is that we can see how these dimensions interact with each other. This gives, we believe, a richer and also a more accurate and nuanced presentation of an industry. However, the increased complexity makes it an approach that lends itself more to understanding rather than the clear-cut conclusions that can follow from the application of simplified models.

\subsection{The Material}

The first is the material, physical, dimension. Here we claim, unsurprisingly, that it is of importance to understand the cargoes, the ships, cargo handling techniques, the geographies of export and import markets, and the people involved in the industry. Related to mainstream business strategy literature, the most direct connection is to the concept of resources. For example, the Resource Dependency Theory states that an organisation is an open system that interacts with its environment and is dependent upon resources in that environment ${ }^{12}$. To understand a reefer company, one must understand the company's access to financial resources, ships, and knowledgeable people. The

11 Badiou, A. 2005. Being and Event, New York: Continuum. Badiou, A. 2009a. Logics of Worlds, London: Continuum. Badiou, A. 20ogb. Theory of the Subject, London: Continuum. Lennerfors, T.T. 2015. Eros, thymos, logos: A study of the spirit of entrepreneurship and innovation at Stena, Gothenburg: BAS. dence perspective, New York: Harper \& Row. Pfeffer, J. 1976. Beyond management and the worker: The institutional function of management. Academy of Management Review, 1: 
Resource Based View (RBV) describes that companies can achieve sustained profitability, by having resources that are valuable, rare, inimitable and nonsubstitutable (VRIN) ${ }^{13}$. Recent RBV studies investigate how resources are combined with other resources to create profitability ${ }^{14}$. RBV has recently started to discuss non-firm resources and how they contribute to a firm's success ${ }^{15}$. Resources are connected and there is interaction between them. The Resource Interaction view ${ }^{16}$ describes how companies have long-standing relationships to other companies. In this theory, one cannot say that a resource in itself is valuable, rare, inimitable and nonsubstitutable, but one must consider the interaction between resources in industrial networks ${ }^{17}$. This view is particularly interesting in the reefer industry which abounds with alliances, clusters, and long-term customer relationships.

To focus on the material dimension means not just to see the material reality as separate artifacts, but rather to conceive of the world as a network of interconnected people and artifacts. These networks can form stable patterns, for example a transport system consisting of trucking bananas to the port, repacking them in pallets, loading them by crane, transporting them across the ocean, and discharging them at the destination.

What we exclude when we single out the material dimensions is the sensemaking, the discourses around this material phenomenon, and the thoughts, desires, and affects concerning this material reality. However, discourses as well as the subjective dimension influence material reality. For example, a

36-46. Hillman, A.J., Withers, M.C. and Collins, B.J. 2009. Resource Dependence Theory: A Review, Journal of Management, 35: 1404-1427.

13 Penrose, E. 1959. The theory of the growth of the firm, New York: John Wiley \& Sons. Barney, J. 1986. Strategic factor markets: Expectations, luck and business strategy. Management science, 32: 1231-1241. Barney, J. 1991. Firm resources and sustained competitive advantage, Journal of management, 17: 99-120.

Kalling, T. 1999. Gaining competitive advantage through information technology - A resource-based approach to the creation and employment of strategic IT resources. Lund: Institutet för ekonomisk forskning, Lunds universitet. Priem, R. \& Butler, J. 2001. Is the resource-based "view" a useful perspective for strategic management research? Academy of management review, 26: 22-40. Kraaijenbrink, J., Spender, J-C. \& Groen, A. 2010. A resource-based view: A review of and assessment of its critiques. Journal of management it, 36: 349-372, Jansson, C. 2012. Företag med framgång: hur resurser kan skapa varaktiga konkurrensfördelar, Göteborg: BAS.

Lavie, D. 2006. The competitive advantage of interconnected firms: an extension of the resource-based view. Academy of Management Review, 31: 638-58.

Håkansson, H. \& Waluszewski, A. 2002. Managing technological development - IKEA, the environment and technology, London: Routledge. Baraldi, E., Gressetvold, E., and Harrison, D. 2012. Resource interaction in inter-organizational networks: Foundations, comparison, and a research agenda, Journal of Business Research 65: 266-276. 
discourse about the importance of high quality, will lead to a focus on changes in the material dimension, for example, the design of cargo holds, cargo gear and hull shape.

People's actions and the result of them are also part of the material dimension. This can concern the habits of loading bananas onto a ship, but also the everyday, habitual work of fixing cargoes in commercial operations. Once again, the focus is on the material and not on the discourses and the subjective attitude of the participants in the practices. This focus on the networks of artifacts and people connects to a few recent streams of thought in business studies. One is actor-network theory, which similarly to our material dimension, does not distinguish between artifacts and people. Both kinds of matter are connected in networked relationships, which directs the development of both actors and networks. Also, it connects to strategy as practice ${ }^{18}$, which to some extent reduces the subjective dimension in strategic work - in other words, rather than claiming that strategies are formed by means of rational, cognitive processes, they claim that material practices (as well as discourses) can significantly influence what strategic actions are taken.

In our description of the various reefer companies we will describe how they have evolved in the material dimensions: what ships they have bought or sold, innovations in ship design or cargo handling, recruitment of people, where the companies are physically located, the logistical systems of which they are part, and so on.

\subsection{The Discursive}

A second dimension is the discursive, which means how we describe, discuss, make sense of, and represent reality. People in a company can for example discursively make sense of the company as an "intuitive" or fast one, alternatively as a company where decision-making processes take a long time. This is certainly related to the material dimension, that a company is really fast or slow, but sometimes the discourses do not correspond to the material reality. Perhaps they once did. Sometimes they also contribute to changing the material. We maintain that it is important to highlight the discursive dimension, and its inclusion into the framework is a reason for why the framework is productive. While other approaches might focus on the real, economic forces in an industry, we hold that language, discourses, sense-making are equally important for the development of an industry. The approach that we have

18 Jarzabkowski, P. 2004. Strategy as Practice: Recursiveness, Adaptation, and Practices-inUse, Organization Studies, 25: 529-56o. Whittington, R. 2006. Completing the Practice Turn in Organization Studies, Organization Studies, 27: 613-634. 
outlined here is similar to approaches in organization studies which have been prevalent since the 1980s, positing that constructed perspectives are crucial for understanding organizations ${ }^{19}$. Very broadly conceived, such studies state that the way we make sense of a situation is very important in how we decide to act upon the situation.

For example, industry reports about the reefer industry are fundamentally discursive. The material reality of fleet sizes, capacity, market rates, and so on are framed by discursive processes of inclusion and exclusion. For example, the segment of smaller reefer ships is frequently excluded from market data. A study which is solely based on market data thus becomes limited due to the discursively constructed nature of the so-called objective material reality. Speed is sometimes measured at "banana draught". In other words, much of the attributes of the material artifacts are created and presented discursively. Sometimes these discourses are produced by habit, being repeated and imitated. Sometimes a new subjective force makes itself visible in the discourses.

The discursive dimension throws light on market expectations, the perceptions of industry insiders, the small-talk at business conferences; all of these have real life business implications. Therefore, when we study the reefer companies from a discursive dimension, we focus on how the persons involved describe their companies, how the company is represented in archival material of various kinds. We also study how the companies make sense of their cargoes, ships, and also other actors, such as competitors. For example, we have already argued that the way we understand the word "reefer" has been an important factor in shaping actions of reefer companies. The same goes with the word "container" as we will show.

\subsection{The Subjective}

The third dimension is the subjective. In general, this zooms in on the human actors that are part of the industry, understanding their perceptions, their views, and their psychological relation to the material and discursive dimensions of the industry. Here, we locate the human actors' agency to initiate material and discursive action. This is the dimension which captures the intentional strategies of actors. We have mentioned above that actions are influenced by discursive and material realities. In a sense, the subjective dimension points to the residual - to the share of human action that is not determined.

19 Boje, D. 1991. The storytelling organization: A study of story performance in an officesupply firm, Administrative science quarterly, 3: 106-126. Czarniawska, B. 1998. A Narrative Approach to Organization Studies, London: Sage. Kristensson Uggla, B. 2002. Slaget om verkligheten. Filosofi, Omvärldsanalys, Tolkning, Stockholm: Symposion. 
Also, it points to the desires and drives, fantasies and imaginations, of the involved actors.

This subjective dimension encompasses the lived experience of friendships, ethnic loyalties, patriotism, or for that matter, dislike which shape business decisions. There have been cases, for example, where ship-owners have firm opinions about who they will do business with. Rather than selling to the highest bidder, social considerations may outweigh rational, economic motivations. These considerations have been largely ignored by the business relationship literature ${ }^{20}$. The subjects' desire for prestige can result in the seeking of contracts with major fruit companies. The pursuit of prestige can lead to a desire to keep ships well-painted - aesthetic considerations.

Moroever, perceptions of reality are part of the subjective dimension. The later years of the reefer industry have been marked by a decline which is as much perceived as it is actual. Perceived decline influences which actions are seen as viable. Similarly, the perceived boom in earlier years led to an investment in reefer ships that flooded the market.

However, most of the strategic literature seems to assume that strategies are formulated rationally, as a means to reach a certain desired end - for example to earn money, to grow the business, or to expand market share. By highlighting the subjective dimension, which for us can consist of much more than a rational, instrumental means-end calculus, we open up for a more nuanced way of understanding the psychologies in the industry.

We further choose to divide this dimension further into three interrelated constituents: eros, thymos, and logos. Eros means a search for instantaneous gratification, the primordial drives, the urges. Thymos covers the posture of pride, desire for recognition. Logos means the rational and structured application of means to reach a certain end. Plato ${ }^{21}$, which has inspired the use of these three concepts, describes their interrelation as that between a charioteer and its two horses. One horse, eros, is constantly seeking to satisfy its desires and appetites, pulling in different directions and subjecting the chariot to uncontrolled, but forceful movements. The other horse, thymos, is stout-hearted, proud, and courageous. It holds its head high and has the confidence to go on. Logos is the charioteer who as far as possible tries to control the two horses. Logos thinks of itself as the locus of strategy, controlling the movement of the chariot, but much of the movement is decided by the interplay between eros and thymos. 
We hold that in order to understand an industry, it is important to also include this subjective dimension. When we describe the actors from a subjective dimension, we will try to get a glimpse of what really motivates them, going beyond the discursive and the material. For example, when it is obvious that an actor is rationally seeking to increase the company's wealth, this would correspond to the dimension of logos. When a company engages in business because of the status and pride it gives the actor, we might be dealing with thymos. And when a company is immersed in the market, making deals for the deals themselves, it might correspond to eros.

Our primary research question is thus developed as: How have the independent reefer operators, individually and collectively, developed in their material, discursive and subjective dimensions since their beginning until today?

\section{7 \\ The Structure of the Book}

In this introduction, we have already indicated several of the factors influencing strategies in the reefer industry, for example seasonality, containerization, and so on. In chapter 2 will set the stage for the corporate narratives that follow. A historical narrative of the macro level factors is presented, thereby describing the environment in which the reefer shipping companies operate. In part two, we will present a number of corporate narratives of the independent reefer operators, describing the history from the perspective of each company. In part three, we describe some important customers and competitors, in order to see the independent reefer operators from another perspective. In part four, we conclude the book by doing an analysis of the strategies of the independent reefer operators, based on our theoretical framework. 